\title{
Basal Cell Carcinoma Multiplicity - a Retrospective Analysis of 899 Biopsy-proven Patients from a Single Institute
}

\section{Mnohopočetný výskyt bazocelulárneho karcinómu - retrospektívna analýza 899 pacientov s biopticky verifikovanými léziami na jednom pracovisku}

\author{
Bartos V. ${ }^{1}$, Kullova M. ${ }^{2}$ \\ ' Department of Pathology, Faculty Hospital in Žilina, Slovak Republic \\ 2 Department of Dermatovenerology, Faculty Hospital in Žilina, Slovak Republic
}

\begin{abstract}
Summary
Background: An interesting clinical feature of basal cell carcinoma (BCC) of the skin is a marked interpatient variation in tumor number, lesion accrual and anatomic distribution. We analyzed a proportion of patients with multiple BCCs in the cohort of pathology report-confirmed cases of BCC and investigated clinicopathological differences between individuals suffering from multiple tumor lesions and patients with a single tumor. Material and Methods: All consecutive patients with primary cutaneous BCCs, who were histologically diagnosed at our Department of Pathology during a 10-year period were enrolled into the study. Results: A cohort of 899 participants with a total of 1,239 histologically proven primary BCCs were assessed. Of them, $728(81 \%)$ had single BCC and $171(19 \%)$ had multiple BCCs. Multiple lesions occurred more frequently in men than women. Mean number of tumors per patient was 1.5 in males and 1.2 in females. Among participants with multiple BCC manifestation, there was a steady increase of the male-to-female ratio with rising tumor number per individual. In the multiple $B C C$ subgroup, the tumors were found more commonly in the trunk and upper limbs, and less frequently in the face. Histologically, these BCCs much more commonly included superficial subtype. There was a positive correlation between the non-aggressive histologic phenotype of $\mathrm{BCC}$ and multiple tumor presentations on the one hand, and the aggressive histologic phenotype of BCC and a single tumor occurrence on the other. Conclusion: Our analysis shows that clinicopathological features associated with multiple BCC manifestations include male gender, tumor location in the trunk and upper extremities, and superficial histological subtype. Focus on this risk profile may be beneficial for clinical screening and may help clinicians in the selection of individuals, who should be followed-up more closely.
\end{abstract}

Key words

basal cell carcinoma - single and multiple manifestations - clinicopathological differences
The authors declare they have no potential conflicts of interest concerning drugs, products, or services used in the study.

Autoři deklarují, že $v$ souvislosti s predmětem studie nemaji žádné komerční zájmy.

The Editorial Board declares that the manuscript met the ICMJE recommendation for biomedical papers.

Redakční rada potvrzuje, že rukopis práce spInil ICMJE kritéria pro publikace zasílané do biomedicínských časopisů.

$\Xi^{\circ}$

Vladimir Bartos, MD, PhD., MSc.

Department of Pathology

Faculty Hospital in Žilina

Vojtecha Spanyola 43

01207 Žilina

Slovak Republic

e-mail:vladim.bartos@gmail.com

Submitted/Obdržané: 21. 12. 2016

Accepted/Prijaté: 17. 2. 2017

doi: 10.14735/amko2017197 


\begin{abstract}
Súhrn
Východiská: Zaujímavou klinickou črtou bazocelulárneho karcinómu (basal cell carcinoma - BCC) kože je výrazná variabilita v počte lézií, rýchlosti ich vzniku a anatomickej distribúcii medzi pacientmi. V našej štúdii sme sledovali zastúpenie pacientov s viacpočetnými BCC v súbore biopticky verifikovaných prípadov BCC a hodnotili sme klinicko-patologické rozdiely medzi osobami s viacpočetnými nádorovými léziami a osobami s potvrdeným len jedným nádorom. Materiál a metodika: Súčastou štúdie boli všetci pacienti s primárnymi BCC kože, ktoré boli histologicky diagnostikované na našom pracovisku patológie počas 10-ročného obdobia. Výsledky: Súbor pozostával z 899 pacientov s celkom 1239 histologicky verifikovaných primárnych BCC. Z nich 728 (81 \%) osôb malo iba jeden a 171 (19 \%) osôb dva a viac BCC. Viacpočetné lézie sa omnoho častejšie vyskytovali u mužov než u žien. Priemerný počet nádorov na jednotlivca bol u mužov 1,5 a u žien 1,2 . V podskupine pacientov $s$ viacpočetnými BCC bol zároveň potvrdený kontinuálny vzostup pomeru mužov a žien s narastajúcim počtom lézií na osobu. $V$ tejto podskupine sa nádory častejšie vyskytovali na trupe a horných končatinách a zriedkavejšie na tvári a omnoho častejšie pozostávali zo superficiálneho histologického typu. Potvrdený bol súvis medzi BCC s neagresívnym histologickým fenotypom a viacpočetnou nádorovou manifestáciou a BCC s agresívnym histologickým fenotypom a singulárnym výskytom nádoru. Záver: Naša analýza poukázala, že klinicko-patologické črty asociované s viacpočetným výskytom BCC zahŕňajú mužské pohlavie, lokalizáciu lézií na trupe a horných končatinách a superficiálny histologický typ. Zameranie sa na tento rizikový profil môže byt' prospešné pre klinický skríning a pomôct’ v selekcii tých pacientov, ktorí by mali byt' dalej dôkladnejšie sledovaní.
\end{abstract}

Klúčové slová

bazocelulárny karcinóm - jednoduchá a viacpočetná manifestácia - klinicko-patologické rozdiely

\section{Introduction}

A striking clinical feature of cutaneous basal cell carcinoma (BCC) is a marked interpatient variation in tumor number, sites and accrual of new lesions [1,2]. While some patients have developed one BCC only, a proportion of patients is affected multiple times by new primary tumor. Further, although most patients demonstrate a single lesion at each presentation, others may suffer from many tumor clusters at different locations $[1,2]$. The rate and extent to which this occurs is quite unclear. In clinical practice, it would be useful to predict the probability for additional new $B C C$ development in the patients who were affected by a first initial lesion. Information on the frequency and timing of these subsequent BCCs may be crucial for adequate follow-up care. A recent meta-analysis showed that approximately $29 \%$ of patients with a first BCC will develop at least one more lesion in their lifetime [3]. Another previous study estimated that 5-year risk for further $B C C$ development in relation to number of prior $\mathrm{BCC}$ is rising as follows: $27 \%$ in $1 \mathrm{BCC}, 49 \%$ in $2 \mathrm{BCCs}, 68 \%$ in $3 \mathrm{BCCs}$, $73 \%$ in $4-5$ BCCs, $78 \%$ in $6-9$ BCCs, and $90 \%$ in $\geq 10$ BCCs [4]. However, these data cannot be universally accepted and are insufficient for reliable individual prediction in dermatological practice. The main risk factors for sporadic BCC include excessive exposure to sunlight, age, male gender, phenotypic characteristics and genetic predisposition. In contrast, the risk factor profile of those individuals who develop many subsequent $B C C$ s during their life is less documented $[5,6]$. Moreover, a recent study gives evidence that the risk factor profile for a second $B C C$ differs from the first BCC [6].

In the current study, we analyzed a proportion of patients with multiple cutaneous BCCs in the cohort of pathology report-confirmed cases of BCC at our institution. Also, we investigated clinicopathological differences between individuals suffering from multiple $\mathrm{BCC}$ lesions and patients with only a single tumor.

\section{Material and methods}

We retrospectively reviewed all consecutive patients with BCCs of the skin whowere histologically diagnosed at the Department of Pathology at the Faculty Hospital in Žilina from January 2007 through December 2016. All participants were registered in the Pathology Archive Computer Program (PACP), from which required histopathological data were extracted. Baseline clinical data needed for the study were obtained from the medical records. To our knowledge, one man suffered from genetically verified Gorlin-Goltz syndrome, that is well-known for its susceptibility to multiple BCCs development $[7,8]$. Relapsing tumors, as well as subsequent re-excisions after inadequate tumor removal, were excluded from the study because they did not represent a primary lesions. A presence of $\geq 2$ primary tumors in a single patient already included in the file was considered BCC multiplicity (multiple $\mathrm{BCC}$ subgroup). When a patient had only one primary $B C C$ registered in the PACP, the case was assigned to single $B C C$ subgroup. Biopsy samples were obtained from a variety of clinical departments (mostly surgery, dermatology, otorhinolaryngology and ophthalmology) at our hospital. Biopsy material was fixed in buffered formalin, embedded in paraffin blocks and stained with hematoxylin and eosin. If necessary, immunohistochemical staining methods were also applied. The histopathological classification of $B C C$ subtypes was done using the latest World Health Organization classification system of skin cancers [9]. Further, all the cases were simply categorized into non-aggressive and aggressive histologic phenotypes, according to our previous paper [10]. Briefly, while the infiltrative (morpheaform), micronodular and metatypical BCC subtypes were classified as aggressive-growth phenotypes, all others were considered to be indolent. Data were collected in a databank, using the SPSS Statistics software. For the statistical analysis, chi-square test was employed and $p<0.05$ was considered significant. 


\section{Results}

Study population and

histopathological data

A cohort of 899 patients with a total of 1,239 histologically proven primary BCCs were assessed. Among them, 467 (51.9\%) were females and 432 (48.1\%) were males resulting in male/female ratio of $1: 1.08$. The average age of participants was 70.4 years without an apparent difference between males (69.8 years) and females (70.4 years). Age ranged from 27 to 97 years and most cases (969; $78.2 \%)$ involved patients older than 60 years. The number of pathology report-confirmed lesions per patient ranged from 1 to 17 , with a mean of 1.3 and a median of 1. Topographic distribution of BCCs was as follows: head and neck (852 cases; 68.8\%), trunk (268 cases; $21.6 \%$ ), upper extremities (86 cases; $6.9 \%$ ) and lower extremities (33 cases; $2.7 \%)$. The three most frequent histologic subtypes present were nodular (500 cases; $40.3 \%$ ), mixed nodular-infiltrative ( 244 cases; $19.7 \%$ ) and superficial (164 cases; $13.2 \%)$. Infiltrative BCC comprised 99 cases $(8.0 \%)$.

Single vs. multiple BCC presentation Of all the 899 patients who entered the study, $728(81.0 \%)$ had single BCC and $171(19.0 \%)$ had multiple BCCs. In the second subgroup, 84 people (49.1\%) were diagnosed with at least two or more BCCs on the same date. A man suffering from Gorlin-Goltz syndrome was found to have a total of 11 primary lesions. He was 35 years old at the time of the last BCC diagnosis. We have confirmed apparent differences in several clinicopathological parameters between the single and multiple BCC subgroups, summarized in Tab. 1. Multiple BCCs occurred more frequently in men than women $(p=0.01)$ attaining a statistical significance. Mean number of tumors per patient was 1.5 in males and 1.2 in females. Among participants with multiple BCC manifestation, we found a steady increase of the male-to-female ratio with rising tumor number per individual (Tab. 2). While this ratio was nearly equal in the set of patients having two lesions, it reached value of $7: 1$ in the set of members manifesting $\geq 7$ primary tu-

Tab. 1. General clinicopathological characteristics of patients with single and multiple BCCs in our study file.

\begin{tabular}{|c|c|c|}
\hline Parameter & $\begin{array}{c}\text { Single } \\
\text { BCC subgroup }\end{array}$ & $\begin{array}{c}\text { Multiple } \\
\text { BCC subgroup }\end{array}$ \\
\hline $\begin{array}{l}\text { number of patients } \\
\text { - male (M) } \\
\text { - female (F) }\end{array}$ & $\begin{array}{l}334^{*} \\
394^{*}\end{array}$ & $\begin{array}{l}98^{*} \\
73^{*}\end{array}$ \\
\hline $\mathrm{M} / \mathrm{F}$ ratio & $1: 1.17$ & $1.34: 1$ \\
\hline number of tumors & 728 & 511 \\
\hline \multicolumn{3}{|l|}{ tumor location } \\
\hline • head (facial part) & $348(47.8 \%)^{*}$ & $169(33.1 \%)^{*}$ \\
\hline - head (extrafacial part) & 159 (21.9\%) & $131(25.6 \%)$ \\
\hline$\cdot$ neck & $25(3.4 \%)$ & 20 (3.9\%) \\
\hline - trunk & $136(18.7 \%)^{*}$ & $132(25.8 \%)^{*}$ \\
\hline - upper extremities & $38(5.2 \%)^{*}$ & $48(9.4 \%)^{*}$ \\
\hline - lower extremities & $22(3.0 \%)$ & $11(2.2 \%)$ \\
\hline $\begin{array}{l}\text { main histological BCC subtype } \\
\text { - superficial } \\
\text { - nodular } \\
\text { - infiltrative }\end{array}$ & $\begin{array}{c}66(9.0 \%)^{*} \\
309(42.4 \%) \\
59(8.1 \%)\end{array}$ & $\begin{array}{c}98(19.2 \%)^{*} \\
191(37.4 \%) \\
40(7.8 \%)\end{array}$ \\
\hline \multicolumn{3}{|l|}{ histological BCC phenotype } \\
\hline - non-aggressive & $471(64.7 \%)^{*}$ & $364(71.2 \%)^{*}$ \\
\hline - aggressive & $257(35.3 \%)^{*}$ & $147(28.8 \%)^{*}$ \\
\hline
\end{tabular}

Tab. 2. Proportion of all 171 patients with multiple BCCs regarding gender and number of tumors per individual.

\begin{tabular}{l|c|c|c|c|}
\hline & $\begin{array}{c}\text { Number } \\
\text { of patients }\end{array}$ & Male (M) & Female (F) & M/F ratio \\
\hline 2 BCC & $105(61.4 \%)$ & 55 & 50 & $1.1 / 1$ \\
\hline $3-4$ BCC & $50(29.2 \%)$ & 30 & 20 & $1.5 / 1$ \\
\hline $5-6$ BCC & $8(4.7 \%)$ & 6 & 2 & $3 / 1$ \\
\hline$\geq 7$ BCC & $8(4.7 \%)$ & 7 & 1 & $7 / 1$ \\
\hline
\end{tabular}

mors. There was a strong correlation regarding tumor topographic distribution. Compared to single BCC patient cohort, in the multiple BCC subgroup, the tumors were found more commonly in the trunk ( $p<0.0001)$ and upper limbs $(p=0.02)$ and vice versa, much less frequently in the face $(p<0.0001)$. Among 171 patients having $\geq 2$ BCCs, 29 subjects $(17.0 \%)$ had truncal lesions only and $100(58.4 \%)$ subjects had all lesions pre- sent explicitly in the extratruncal sites. Within these two subsets, male gender was more prone to have solely truncal tumors (Tab. 3). Histologically, in multiple BCC subgroup, tumors included the superficial subtype much more commonly ( $p<0.0001)$. Although no statistical significance was found among all other histologic subtypes, there was a positive correlation $(p<0.02)$ between the non-aggressive histologic pheno- 
Tab. 3. Gender distribution of patients having multiple BCCs divided into "truncal lesions only" and "extratruncal lesions only" cathegories.

Remaining cases comprising a simultaneous occurrence of both, truncal and extratruncal lesions in a single individual are not included in table.

\begin{tabular}{l|c|c|c|}
\hline & Male (M) & Female (F) & M/F ratio \\
\hline truncal lesions only & 18 & 11 & $1.63 / 1$ \\
\hline extratruncal lesions only & 49 & 51 & $1 / 1.04$ \\
\hline BCC - basal cell carcinoma & & & \\
\hline
\end{tabular}

type of BCC and multiple tumor presentation on the one hand, and the aggressive histologic phenotype of BCC and a single tumor occurrence on the other.

\section{Discussion}

Currently, BCC of the skin is the most common malignancy in humans. In fact, it represents a heterogeneous group of tumors with variable clinical behavior and histomorphology [11]. Many patients are prone to developing multiple primary lesions at different body sites. As a result, the incidence of persons affected by BCC probably underestimates the true incidence of this neoplasia due to the common occurrence of multiple primary lesions within individuals [12]. In the literature, the percentage of patients with more than one primary $\mathrm{BCC}$ varied from $12 \%$ to $46 \%[2,5,6,12-16]$ and mean number of tumors per individual ranged from 1.5 to $1.9[15,17]$. This variability is due to several factors, such as the total number of participants, follow-up periods and active surveillance. In our retrospective analysis, $19 \%$ of all 899 patients with biopsy report-confirmed cutaneous BCC registered in our pathology database had $\geq$ primary lesions, and the mean number of tumors per individual was 1.3. These values seems to be slightly lower compared with the studies mentioned above. However, we only aimed to determine a proportion of the individuals with multiple BCCs in defined cohorts of patients without their precise follow-up. We realize that it is a crucial limitation of the study, since we could assess only data that were available within our pathology database. Further, we may have missed BCC diagnoses that were not made based on histopathology, leading to misclassification bias, although we suppose that such cases comprised a very small percentage.

The risk factor profile of the individuals who develop repeated new BCCs during their life is relatively poorly elucidated. The results of several previous studies suggested that the key predisposing factors for multiple BCC development include younger age and superficial BCC subtype at the time of the first diagnosis $[5,6,18]$, red hair phenotype [5], initial or frequent tumor location in the trunk $[1,4,5,6,18]$ or the upper extremities [5] and clinical manifestation with tumor clusters [2]. Further, some studies $[12,16,17]$ have shown that men have higher risk of developing multiple BCCs than women. On contrary, Mantese et al. did not find statistically significant difference between genders regarding the number of lesions [15].

It seems very unlikely that the differences between single vs multiple $B C C$ development result from different UVR exposure patterns solely. Some authorities $[1,2]$ believe that this reflects the heterogeneity of the BCC case group, faster tumor accrual and initial cluster presentation may suggest reduced effectiveness in immune surveillance. However, the genetic factors and individual characteristics associated with susceptibility to this cancer are still unclear. Even the question on clonality of neoplastic cells in persons suffering from multiple BCC has not been clarified until now. The results of some authors [19] suggested that their origin is polyclonal and may not arise from the same progenitor cell. However, another molecular study [20] contradicts such hypothesis.
Several clinicopathological differences exist depending on whether the patients have single or multiple BCCs during their lifetime. We have found that patients with multiple BCC lesions showed a higher prevalence of male gender. In addition, while there was nearly an equal proportion of men and women in the subset of members with two BCCs, the male-to-female ratio continuously increased with the number of additional lesions. These findings suggest that men are more prone to develop a larger number of BCCs than women, corroborating observations from some previous studies $[12,16,17]$. Further, we confirmed that in the subgroup of patients with multiple BCCs, the tumors developed more frequently in the back and upper limbs and vice versa, much less frequently in the face. Histologically, these BCCs more commonly consisted of the superficial subtype and less commonly of the nodular and the infiltrative ones. These data are consistent with the results published by Kiiski et al. [5]. Of note, Kiiski et al. [5] observed no associations between both, single vs multiple BCC subgroups and cumulative UVR exposure during one's lifetime. Another recent study [6] demonstrated that no significant influence was found for phenotype status and UVR-related characteristic on the development of a second BCC after a prior one. We are not able to comment on those findings, since we do not have sufficient information on phenotype and lifetime behavior of the patients and our work has not been focused on this topic.

In conclusion, BCC multiplicity is a frequent finding in a routine dermatological practice. Our analysis shows that clinicopathological features associated with multiple BCC manifestations include male gender, tumor location in the trunk and upper extremities and superficial histologic subtype. Since identifying which patients will most probably manifest multiple lesions throughout life allows earlier removal of new lesions with reduced morbidity, focusing on this risk profile may be beneficial for clinical screening and may help clinicians in the selection of individuals, who should be followed-up more closely. 


\section{Acknowledgments}

The authors wish to thank MUDr. Zacharová Olga and MUDr. Pokorný Dušan for their educational support.

\section{References}

1. Ramachandran S, Fryer AA, Smith A et al. Cutaneous basal cell carcinomas: distinct host factors are associated with the development of tumors on the trunk and on the head and neck. Cancer 2001; 92(2): 354-358.

2. Ramachandran S, Fryer AA, Smith AG et al. Basal cell carcinoma: tumor clustering is associated with increased accrual in high risk subgroups. Cancer 2000; 89(5): 1012-1018.

3. Flohil SC, van der Leest RJ, Arends LR et al. Risk of subsequent cutaneous malignancy in patients with prior keratinocyte carcinoma: a systemic review and meta-analysis. Eur J Cancer 2013; 49(10): 2365-2375. doi: 10.1016/j. ejca.2013.03.010.

4. Karagas MR, Greenberg ER. Unresolved issues in the epidemiology of basal cell and squamous cell skin cancer. In: Mukhtar H (ed). Skin Cancer: Mechanisms and Human Relevance. Boca Raton: CRC Press 1995: 79-86.

5. Kiiski V, de Vries E, Flohil SC et al. Risk factors for single and multiple basal cell carcinomas. Arch Dermato 2010; 146(8): 848-855. doi: 10.1001/archdermatol.2010. 155.
6. Verkouteren JA, Smedinga $H$, Steyerberg EW et al. Predicting the risk of a second basal cell carcinoma.

J Invest Dermatol 2015; 135(11): 2649-2656. do 10.1038/jid.2015.244

7. Plevová P, Krutílková V, Puchmajerová A et al. Gorlinův syndrom. Klin Onkol 2009; 22 (Suppl): S34-S35.

8. Plevová P, Šilhánová E, Foretová L. Vzácné hereditární syndromy s vyšším rizikem vzniku nádorů. Klin Onkol 2006; 19 (Suppl): S68-S75.

9. LeBoit P, Burg G, Weedon D et al. World Health Organization Classification of Tumours, Pathology and Genetics of Skin Tumours. Lyon: IARCPress 2006: 355.

10. Bartos V, Adamicova K, Kullova M et al. Comparision of histological types of primary and subsequent relapsing basa cell carcinomas of the skin. Klin Onkol 2012; 25(4): 262-266.

11. Bartoš V, Adamicová K, Kullová M et al. Basal cell carcinoma of the skin - biological hehaviour of the tumor and a review of the most important molecular predictors of disease progression in pathological practice. Klin Onko 2011; 24(1): 8-17.

12. Richmond-Sinclair NM, Pandeya N, Ware RS et al. Incidence of basal cell carcinoma multiplicity and detailed anatomic distribution: longitudinal study of an australian population. J Invest Dermatol 2009; 129(2): 232-238. doi: 10.1038/jid.2008.234.

13. Karagas MR, Greenberg ER, Spencer SK et al. Increase in incidence rates of basal cell and squamous cell skin cancer in New Hampshire, USA. New Hampshire Skin Cancer Study Group. Int J Cancer 1999; 81 (4): 555-559.

14. Raasch BA, Buettner PG. Multiple nonmelanoma skin cancer in an exposed Australian population. Int J Dermatol 2002; 41(10): 652-658.

15. Mantese OA, Gomides AD, Berbert VC et al. Basal cell carcinoma - analysis of 300 cases observed in Uberlândia - MG, Brazil. An Bras Dermatol 2006; 81(2): 136-142. 16. Flohil SC, Koljenović S, de Haas ER et al. Cumulative risks and rates of subsequent basal cell carcinomas in Netherlands. Br J Dermatol 2011; 165(4): 874-881. doi: 10.1111/j.1365-2133.2011.10488.x

17. Souza CF, Thomé EP, Menegotto PF et al. Topography of basal cell carcinoma and their correlations with gender, age and histologic pattern: a retrospective study of 1042 lesions. An Bras Dermatol 2011; 86(2): 272-277.

18. Lovatt TJ, Lear JT, Bastrilles J et al. Associations between ultraviolet radiation, basal cell carcinoma site and histology, host characteristics, and rate of development of further tumors. J Am Acad Dermatol 2005; 52(3 Pt 1): 468-473.

19. Heitzer E, Quhenberger F, Wolf P. Polyclonality of multiple sporadic basal cell carcinomas. J Invest Dermatol 2009: 129(6): 1586-1589. doi: 10.1038/jid.2008.411.

20. Shulman O, Laitman Y, Vilan A et al. Monoclonal origin of anatomically distinct basal cell carcinomas. J Invest Dermatol 2006; 126(3): 676-679. 